\title{
IMPLEMENTATION OF TECHNOLOGY BASED SCIENCE LITERATION IN IMPROVING STUDENT'S CRITICAL THINKING ABILITY ON SCIENCE LEARNING AT SD 04 RANTAUPRAPAT LABUHANBATU DISTRICT
}

\author{
Rismawati Lubis ${ }^{1}$ \\ Open University, Indonesia \\ E-mail : rismawati@gmail.com \\ Rosmawaty ${ }^{2}$ \\ Open University, Indonesia \\ E-mail : rosmawaty@gmail.com \\ Sri Listyarini ${ }^{3}$ \\ Open University, Indonesia \\ E-mail : sri.listyarini@gmail.com
}

\begin{abstract}
This type of research is descriptive qualitative. The purpose of this study was to analyze the application of technology-based scientific literacy in improving students critical thinking skills in science learning at SD 04 Rantauprapat. Objects were obtained by purposive sampling. The object in this study was taken as many as 56 for respondents, namely fourth grade students of SD Negeri 04 Rantauprapat, namely Class IVA totaling 28 students and Class IVB totaling 28 students for a questionnaire of students critical thinking abilities. The ability to think critically of students in this case includes Reason, Situation, Clarity, Overview, and Inference with the acquisition of technology-based scientific literacy in science learning at SD 04 Rantauprapat, namely: student frequency those who think that the Reason aspect is above an average of 48 students or 92.9\%; the frequency of students who think the Situation aspect is above the average of 46 students or 82.1\%; the frequency of students who think that the clarity aspect is above the average is 46 students or $82.1 \%$; the frequency of
\end{abstract}


students who think about the Aspects of Examination (Overview) is above the average of 34 students or 60.7\%; and the frequency of students who think inference (Inference) above the average is 34 students or $60.7 \%$. Based on the analysis of students 'scientific literacy abilities made in written tests and interviews, it can be seen how the students abilities in solving science questions. The results are as follows. a) almost all students science content is still low, this means that most students do not understand the concept of science, $b$ ) recognize scientific questions, there are no errors for all students, c) in identifying scientific evidence and phenomena, all students are able to read the data provided, d) in drawing conclusions, almost all students are able to do well, e) in communicating conclusions, almost all students are able to do it well, f) almost all students show understanding of concepts, $g$ ) in science applications, almost all students are able to apply them well.

Keywords: Technology-Based Science Literacy, Critical Thinking Ability

\section{A. Introduction}

The low ability of scientific literacy was stated by Fathurohman, et al (2014) in their research, which stated that the low scientific literacy skills of Indonesian students were influenced by many things, including the curriculum and education system, the choice of teaching methods and models by teachers, learning facilities and facilities, learning resources, teaching materials, and so on. One of the factors that directly intersect with the learning activities of students and affect the low literacy skills of Indonesian students is the selection of teaching methods and models by the teacher. In addition, the Ministry of National Education (2011) states that the current trend of science learning is only oriented to science products. This is shown by the large number of students who study science by memorizing concepts, principles, laws, and theories. As a result, the dimensions of attitude, process, and application cannot be achieved optimally. Therefore, it is necessary to make changes in science 
learning with scientific literacy.

Researchers made observations at SD 04 Rantauprapat Labuhanbatu Regency. Based on the results of observations, the science learning process that has been implemented has not fully involved the direct experience of students science process skills. This results in the aspects of student science and technology literacy which include aspects of concept knowledge, application of concepts in certain contexts, science process skills and students scientific attitudes have not been achieved optimally. In the aspect of conceptual knowledge that can be seen in the results of the student learning evaluation in the form of the Daily Test Test, the percentage of students who have completed learning is $61.8 \%$. This means that there are still many students who have not finished learning in science learning. Furthermore, Science process skills and students scientific attitudes are also not visible because learning activities do not involve active students to carry out experimental activities. The ability of students to relate the concepts that have been studied with elements of the environment, technology and society, the ability of students to associate concepts with these elements has not been seen.

Related to the learning process, Muhibbin (2011) in his research also revealed the same thing, the results of this study explained that in conveying learning, the teacher did not start by presenting scientific phenomena, so students seemed to have difficulty linking the concepts studied with the phenomena that occurred in life In addition, the questions given are still limited to questions that require memory and understanding of concepts, so students are not accustomed to working on questions that use discourse and have difficulty working on questions that lead to technology-based measurement of Science Literacy. 
The problems in the learning process above, give an important point that it is desirable in science learning to use learning methods that are compatible with the characteristics of students. This was expressed by Soejadi (2000) that science learning should use a learning model that is better and in accordance with the characteristics of elementary school students. In addition to paying attention to student characteristics, teachers must also pay attention to material characteristics. Through the use of contextual material, students will better understand the learning material and apply it in everyday life. Contextual material is not sufficient to improve students technology-based Science Literacy, because sometimes teachers are not able to apply appropriate learning models.

The learning that will be discussed in this research, especially technology-based scientific literacy, discusses how the teacher's role in literacy learning through students critical thinking skills. Next, we will discuss the role of literacy through students critical thinking skills that are integrated in classroom learning activities. The students critical thinking skills are expected to refer to the implementation of the 2013 curriculum. The technological aspects used in this study are in the form of computers with animation media. Animation Media is a media in the form of moving images accompanied by sound and is a development of Science and Technology (Science and Technology). The use of this animation is inseparable from computer tools. Animation is a collection of images that are processed in such a way as to produce movement. Animation creates the illusion (illusion) for movement by exposing or displaying a sequence of images that change gradually (progressively) at high speed. Animation is used to describe the movement of an object, in this case the object used is an erupting mountain. The animation media will be displayed in the learning process to support teacher learning methods in improving 
critical thinking skills by using science literacy learning science.

\section{B. Method}

\section{Research Subjects and Objects}

The subjects studied were 56 student respondents in class IV SD Negeri 04 Rantauprapat, namely Class IVA totaling 28 students and Class IVB totaling 28 students for a questionnaire on students critical thinking abilities. The reason for choosing this class was because scientific literacy in grade IV had never been carried out, for this reason the researcher conducted research in that class.

The object of this research is the students critical thinking skills based on science literacy based on animated videos.

\section{Research design}

Prepare RPP for the application of Technology-Based Science Literacy with animated video media

Competency standards

7. Understand the changes that occur in nature and its relationship with use of natural resources Basic competencies

7.6 Identifying a natural event happened in Indonesia and its impact for living things and the environment
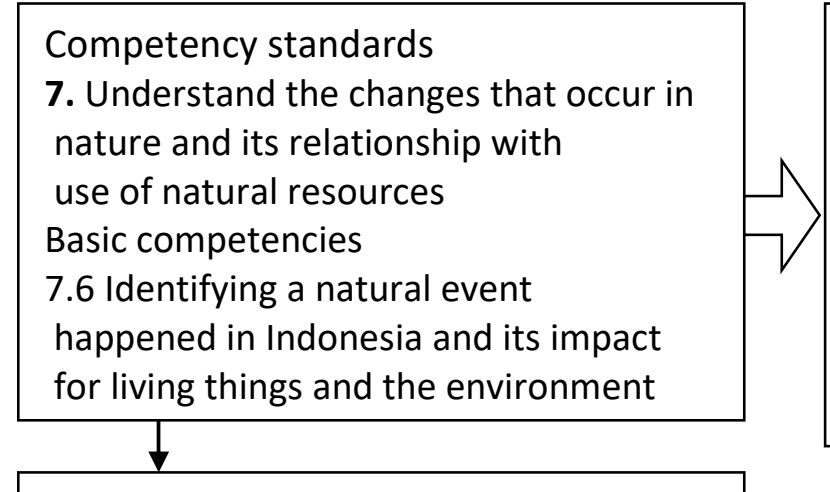

Natural events taken in the RPP material are volcanoes. The material will be given a direct experiment to students in the form of practice with the tools and materials prepared.

Indicator

7.6.1 Describe natural volcanic eruptions

7.6.2 Describe the impact of natural volcanic eruptions on living things and the environment

7.6.3 Describe the hazards posed by volcanic activity

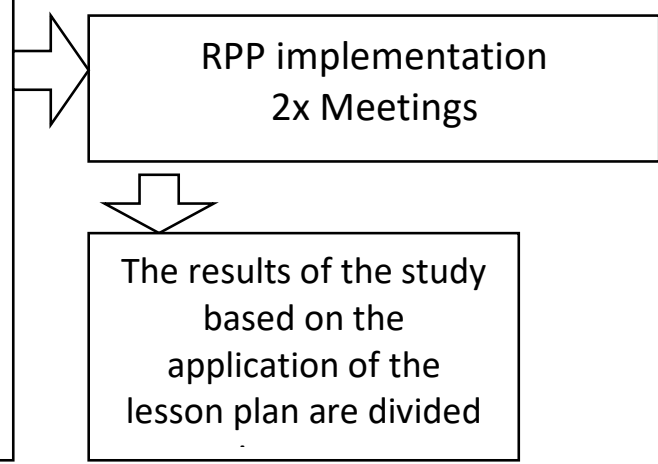




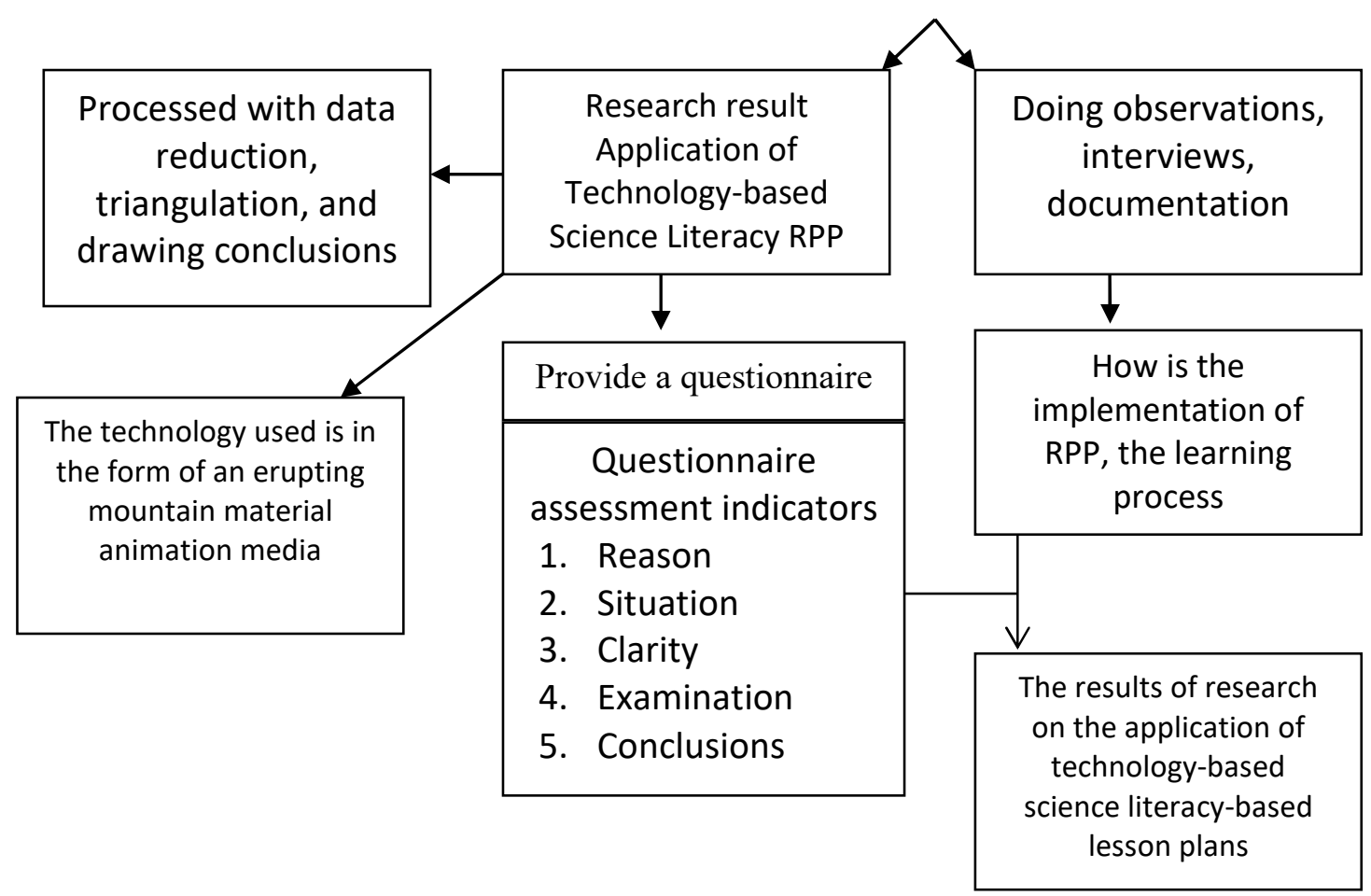

Figure 1. The design of the application of technology-based scientific literacy (animated video media) in improving students critical thinking skills.

\section{Data Collection Procedure}

In accordance with the research instrument that has been described, the data collection procedures carried out in this study are observation, questionnaire distribution, interviews, and documentation study.

1. Observation sheet

Observation as a data collection technique has specific characteristics when compared to other techniques, namely interviews and questionnaires. If interviews and questionnaires always communicate 
with people, then observation is not limited to people, but also other natural objects. Data collection with observation sheets was carried out during the research process. Observation is intended to determine the suitability of the application of technology-based Science Literacy with students thinking abilities through science learning at SD 04 Rantauprapat Labuhanbatu.

Direct observations were made to determine with certainty how the process of implementing IPAdi learning at SD 04 Rantauprapat Labuhanbatu. In this case the researcher observes the teacher when carrying out the learning process in the classroom by applying unstructured observations. Unstructured observations are observations made without using observation guidelines, so that researchers develop their observations based on developments that occur in the field.

2. Test

The test in this study was given to 56 students. It is intended that data collection in this study can be obtained more accurately.

The test used in this study includes an objective test form whose application is in the form of technology-based scientific literacy short answer questions with students thinking abilities through learning science at SD 04 Rantauprapat Labuhanbatu.

3. Interview

Interviews are a process of interaction between researchers and informants in order to obtain information directly. In this study the researcher interviewed the informants directly (face to face) with the interview instructions that had been compiled by the researcher. In interviewing informants, researchers used a recording device so that the results of the interview could be played back. 
In order for the interview to be effective, there are a number of stages that must be passed, namely; 1 ) introduce yourself, 2 ) explain the purpose of arrival, 3) explain the interview material, and 4) ask questions.

The interview conducted by the researcher is an in-depth / free interview, that is, a free interview without a pre-prepared question guide so that the atmosphere is lively, and can be done many times. This is done by researchers in the hope that the information obtained is more accurate.

4. Documentation

Documentation, namely the search for data carried out by researchers in the form of notes, books, syllabus, lesson plans, photos, videos and so on, which can support the results of this research. This documentary data is supporting data / complementary to primary data.

Before conducting the research, the researcher first made observations at SD 04 Rantauprapat Labuhanbatu. After that the research spread out the train that had been provided. In addition to providing a questionnaire, the researcher also interviewed several informants to support the data collection.

\section{Finding and Discussion}

1. Results

\section{Analysis of Students Critical Thinking Ability}

The results of students scientific literacy research were obtained from a questionnaire instrument. After the researchers conducted research at SD Negeri 04 Rantau Prapat with the method of observation, documentation, interviews, the research findings could be explained. The following table 4.1 below presents the results of students critical thinking skills with the application of Technology-Based Science Literacy: 


\section{a. Aspect of Reason}

data on the frequency distribution of the ability to think in the Reason aspect with intervals of $26-30$ by $0 \%, 31-35$ by $7.1 \%, 36-40$ by $7.1 \%, 41-45$ by $23.2 \%, 46-50$ by $55.4 \%$, and $51-55$ at $7.1 \%$. This shows that the ability to think aspects of reason (reason) of students is higher with the frequency of students who think aspects of reason (reason) above the average of 48 students or equal to $92.9 \%$.

The following is a diagram of the frequency and percent of students thinking ability aspects of reasoning:

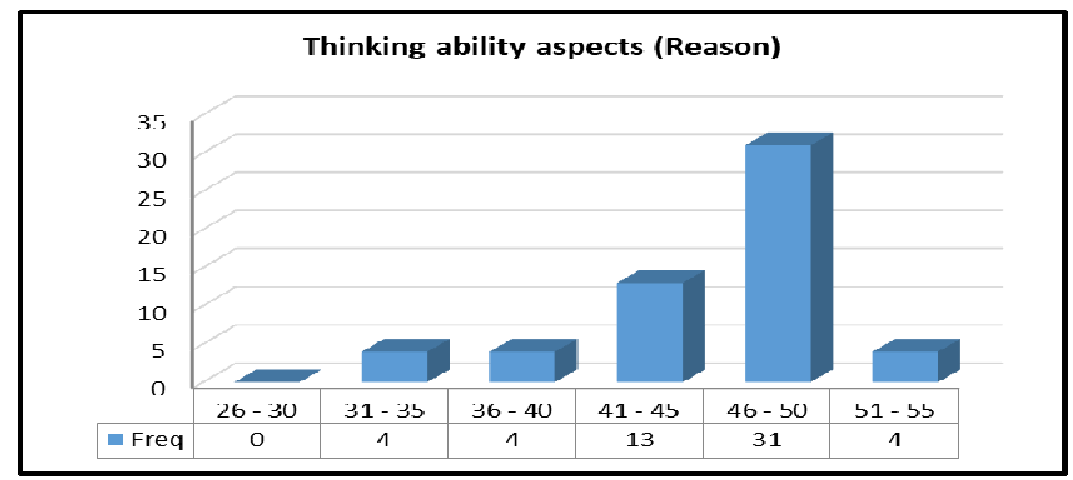

Figure 1. The Frequency of Students Thinking Ability Aspects of Reason

b. Ability to think Situation Aspects

Data distribution of the frequency of students thinking ability in Situation aspects with intervals of $1-5$ is $0 \%, 6-10$ is $0 \%, 11-15$ is $17.9 \%$, $16-20$ is $35.7 \%, 21-25$ is $37,5 \%$, and $26-30$ by $8.9 \%$. This shows that the students thinking ability in Situation aspects is higher with the frequency of students who think Situation aspects are above the average of 46 students or $82.1 \%$. 


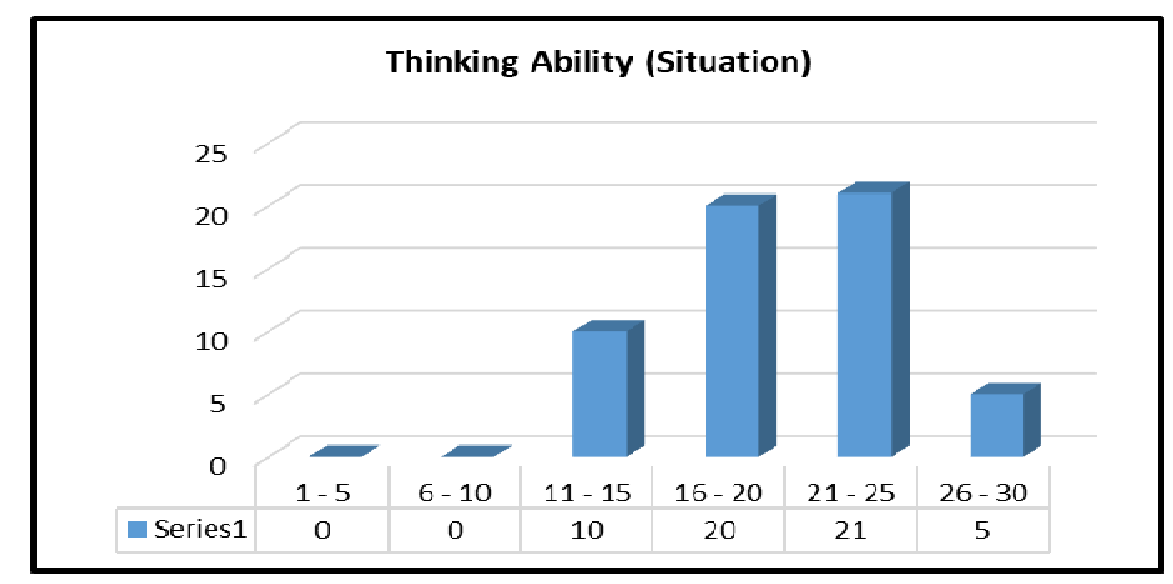

Figure 2. The Frequency of Students Ability to Think Situation Aspects

c. Ability to Think Aspects of Clarity

data on the frequency distribution of students clarity aspects of thinking ability with intervals of 1 - 5 of $0 \%, 6$ - 10 of $16.1 \%, 11-15$ of $62.5 \%, 16-20$ of $16.1 \%$, and $21-25$ by $5,4 \%$, . This shows that the ability to think in the Clarity aspect of students is higher with the frequency of students who think that the Clarity aspect is above the average of 46 students or by $82.1 \%$.

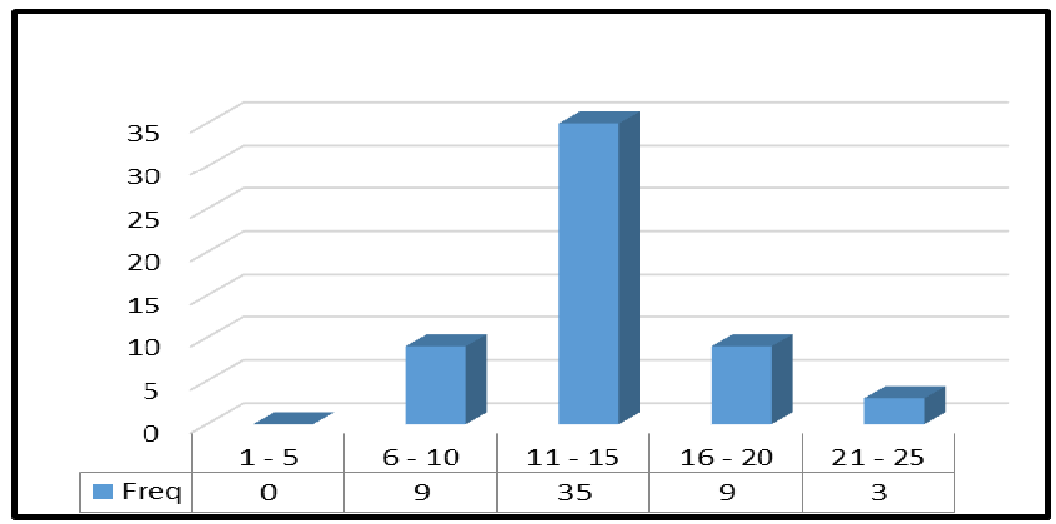

Figure 3. The frequency of the ability to think in terms of clarity 
d. Ability to think Aspects of Examination (Overview)

Data on the frequency distribution of students original thinking skills with intervals of $1-5$ are $0 \%, 6-10$ are $39.3 \%$, and $11-15$ are $60.7 \%$. This shows that the students Overview of the Thinking Ability (Overview) is higher with the frequency of students who think the Overview Aspect is above the average of 34 students or $60.7 \%$.

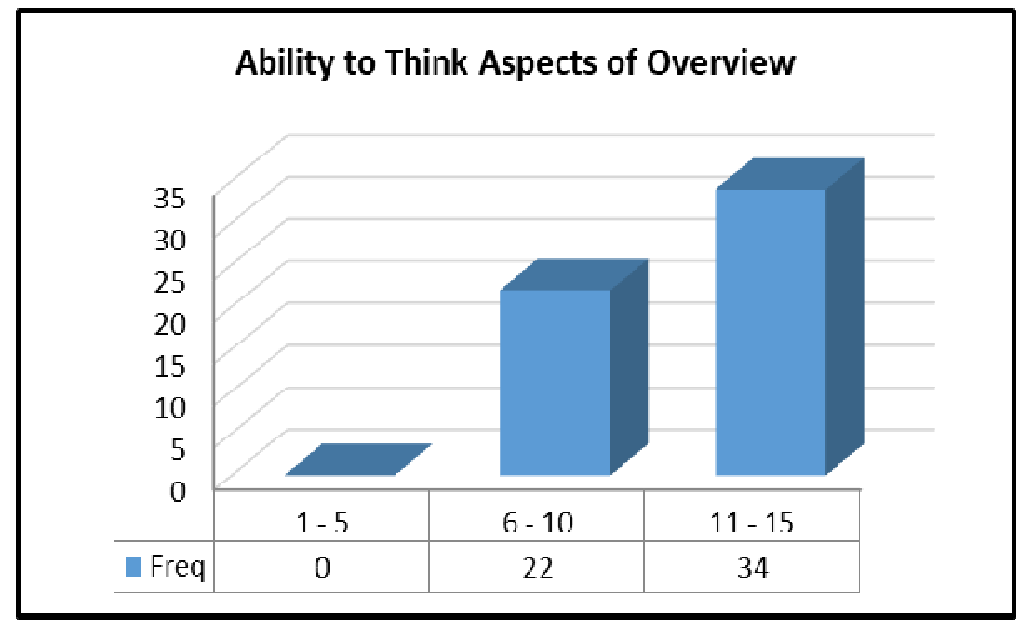

Figure 4. The Frequency of Students Thinking Ability Aspects of Overview

e. Ability to think Conclusions (Inference)

Data on the frequency distribution of students original thinking skills with intervals of $1-5$ are $0 \%, 6-10$ are $39.3 \%$, and $11-15$ are $60.7 \%$. This shows that the students inference thinking ability is higher with the frequency of students who think inference (inference) above the average of 34 students or $60.7 \%$. 


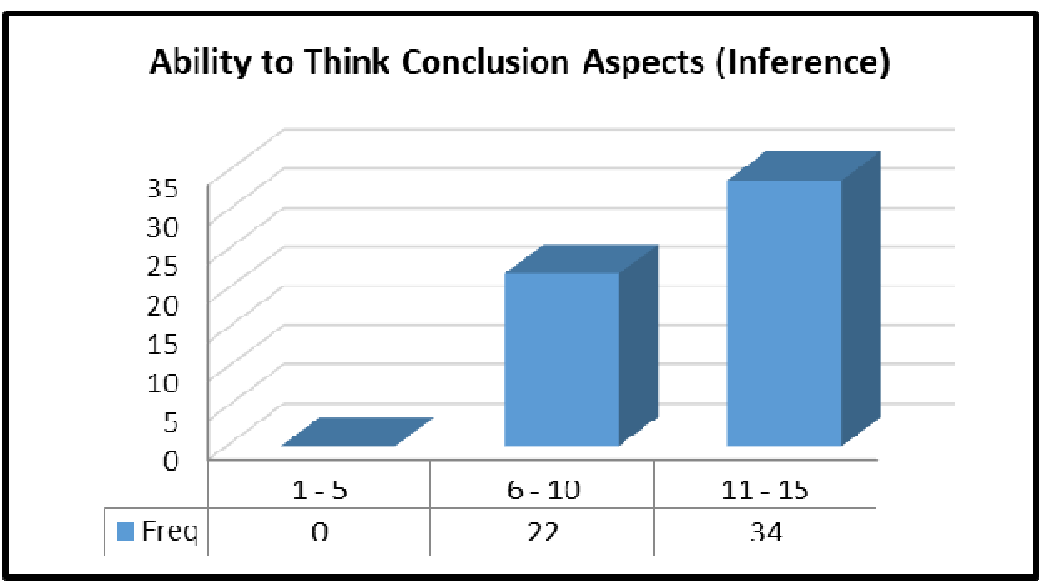

Figure 5. The Frequency of Students Conclusion Thinking Ability (Inference)

The frequency distribution Critical thinking skills as follows.

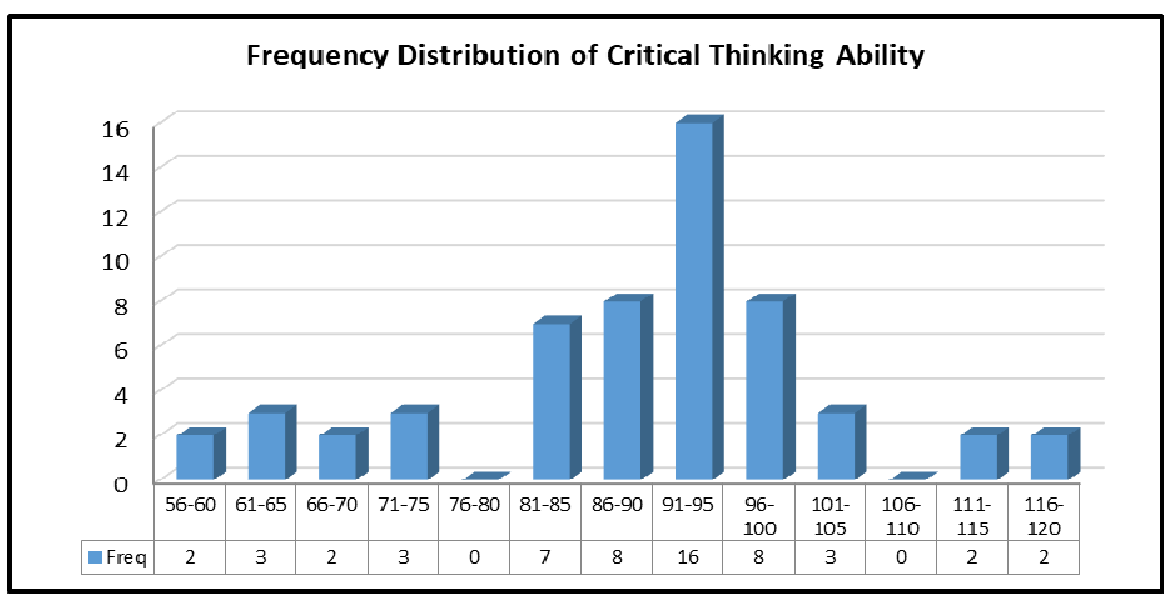

Figure 6. Frequency Distribution of Critical Thinking Ability by Using the Application of Technology-Based Science Literacy

Based on the analysis of students critical thinking skills, it was found that in terms of revealing facts needed to solve problems, all students were able to do well, in providing logical arguments from the facts and evidence, most students did well, in analyzing arguments effectively, almost all students are able to do so, and in solving problems by 
explaining from various points of view, all students are able.

Students with critical thinking skills who have scientific literacy skills with the pattern shown in Figure 6 below.

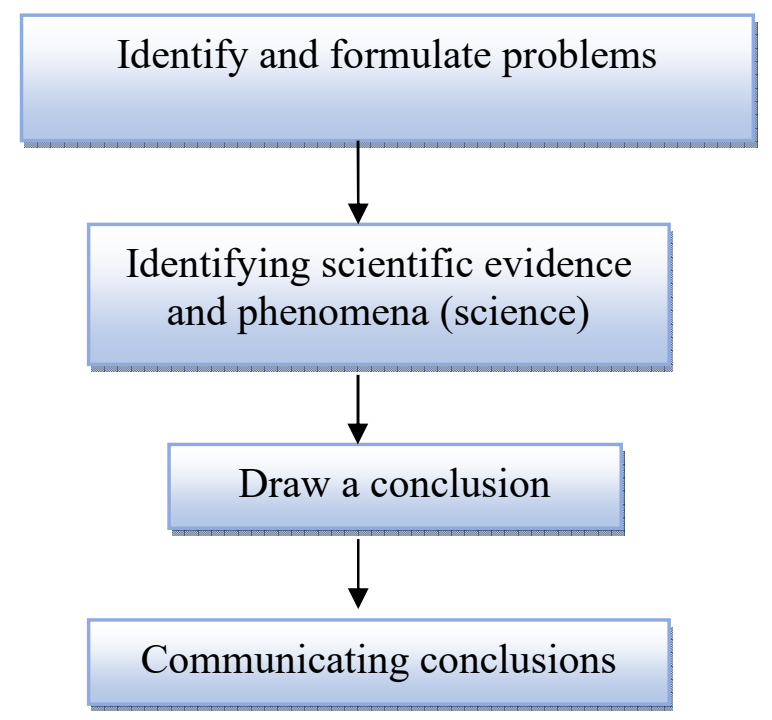

Figure 6. Thinking Patterns of Students with Critical Thinking Ability

\section{Discussion}

Critical thinking is a directional and clear process used in mental activities such as solving problems, making decisions, persuading, analyzing assumptions, and conducting scientific research. Critical thinking is the ability to argue in an organized manner, the ability to systematically evaluate the weight of personal and other people's opinions. To start learning through the application of technology-based scientific literacy, the researcher first prepares a Learning Implementation Plan (RPP), learning materials, student worksheets as discussion material to determine the extent to which students critical thinking skills in this case include reasons, situation, Clarity, Examination (Overview), and Conclusions (Inference). 
The learning context that is applied in the Mount Eruption material leads students to first be able to understand the concept of a natural phenomenon then think about questions that can be raised through natural events, in this activity, students process to think critically about the material presented by the teacher. This is in accordance with the research report of Sa'adah et al (2017) which found a link between critical thinking skills and concept mastery. Likewise with the research report conducted by Alatas (2014) which found a relationship (correlation) between concept mastery and critical thinking skills.

In some parts of the concept, there are videos that show the application and explanation of a concept accompanied by an oral explanation (audio) and several animations that represent concepts that cannot be seen directly by students in everyday life. This video can strengthen the explanation of the material that has been learned by students. There are student learning activities to learn a concept in the form of reading text, explanation of concepts related to the material, pictures that can help students easily understand abstract concepts and knowledge related to the concepts to be studied.

The results of this study also sharpen the results of Rahayuni's (2016) study, which found a link between critical thinking skills and scientific literacy, although there was no analysis of whether the two variables had an effect on conceptual mastery. The same thing was also found in the results of his research by Pamungkas (2018) that the achievement of students scientific literacy is influenced by the ability to think critically. Scientific literacy can develop in line with the development of academic reasoning and thinking skills in the context of student life so that the mastery of science learning material through Mount Meletus material is beneficial. The ability of students to give meaning, interpret, 
translate, and express their understanding is influenced by the science literacy variable and the critical thinking skill variable.

Based on the analysis of students scientific literacy abilities based on technology in improving their critical thinking skills. The results are as follows.

a. The student science content is almost entirely good, this means a large partar students understand the concept of science.

b. Recognizing scientific questions, there are no errors for all students.

c. In identifying scientific evidence and phenomena, all students are mampu reads the data given.

d. In drawing conclusions, almost all students able to do well.

e. In communicating conclusions, almost all students able to do well.

f. Almost all studentsa indicates understanding of the concept.

g. In the application of science, almost all students are able to apply it well

\section{Conclusion}

Based on the results of research and discussion, it can be concluded that students critical thinking abilities in solving technologybased science literacy problems are as follows:

1. Ability students critical thinking in this case includes Reason, Situation, Clarity, Overview, and Inference with the acquisition of technologybased scientific literacy in science learning at SD 04 Rantauprapat, namely: the frequency of students who think aspects of Reason in above the average of 48 students or $92.9 \%$; the frequency of students who think the Situation aspect is above the average of 46 students or 82.1\%; the frequency of students who think that the clarity aspect is above the average is 46 students or $82.1 \%$; the frequency of students 
who think about the aspects of examination (Overview) is above the average of 34 students or $60.7 \%$; and the frequency of students who think inference above the average is 34 students or $60.7 \%$.

2. The application of technology-based scientific literacy in science learning at SD 04 Rantauprapat obtained an increase in the value of learning outcomes due to changes in learning methods or models based on scientific literacy in the learning process which includes activities and activities to train and develop thinking skills, especially students critical thinking skills. Critical thinking skills are very important for students mindset, critical thinking is now widely viewed as a basic competency, such as reading and writing that need to be mastered.

3. The application of technology-based scientific literacy in improving students critical thinking skills in science learning at SD 04 Rantauprapat, obtained:

- The students science content is almost entirely good, this means that most students understand the concept of science,

- Recognizing scientific questions, no errors for all students,

- In identifying scientific evidence and phenomena, all students are able to read the data provided,

- In drawing conclusions, almost all students are able to do well,

- In communicating conclusions, almost all students were able to do it well,

- Almost all students show an understanding of the concept,

- In the application of science, almost all students are able to apply it well. 


\section{Bibliography}

Alatas, F. (2014). Hubungan pemahaman konsep dengan keterampilan berpikir kritis melalui model pembelajaran treffinger pada mata kuliah fisika dasar. EDUSAINS, 6(1), 88-96.

Depdiknas. 2011. Panduan pengembangan pembelajaran IPA secara terpadu. Direktorat Jenderal Pendidikan Dasar Depdiknas. Jakarta.

Fathurohman, A., Zulherma, dan F. Kurnia. 2014. Analisis Bahan Ajar Fisika SMA Kelas IX di Kecamatan Indralayu Utara Berdasarkan Kategori Literasi Sains. Jurnal Inovasi dan Pembelajaran Fisika. 1 (1): 43-47.

Juhji dan Mansur. 2020. Pengaruh Literasi Sains Dan Keterampilan Berpikir Kritis Terhadap Penguasaan Konsep Dasar Biologi. EDUSAINS, p-ISSN 1979-7281 e-ISSN 2443-1281.

Latip, Abdul dan Permanasari, A. (2015). Pengembangan Multimedia Pembelajaran Berbasis Literasi Sains untuk Siswa SMP pada Tema Teknologi, Jurnal Edusains : Vol 7, No. 2: 12 - 14

Muhibbin, S. (2011). Psikologi Pendidikan, Bandung: Remaja Rosdakarya.

Pamungkas, Z. S., Aminah, N. S., \& Nurosyid, F. (2018). Analisis kemampuan berpikir kritis siswa dalam menyelesaikan soal literasi sains berdasarkan tingkat kemampuan metakognisi. EDUSAINS, 10(2), $254-264$.

Rahayuni, G. 2016. Hubungan keterampilan berpikir kritis dan literasi sains pada pembelajaran ipa terpadu dengan model pbm dan stm. Jurnal Penelitian Dan Pembelajaran IPA, 2(2), 131-146.

Sa'adah, S., Sudargo, F., \& Hidayatullah, T. (2017). Penguasaan Konsep Mahasiswa pada Mata Kuliah Zoologi Vertebrata Melalui TeamBased Learning dan Hubungannya Dengan Keterampilan Berpikir Kritis.

Soejadi, R., (2000), Kiat Pendidikan IPA di Indonesia, Jakarta : Depdiknas. 